\title{
Information System Public Administration Services Parianum Village, Muara Bengkal Sub- District
}

\author{
Amin Rais \\ Software Engineering Technology, \\ Agriculture Polytechnic of \\ Samarinda, 75242, Indonesia \\ serahku86@gmail.com
}

\author{
Suswanto * \\ Software Engineering Technology, \\ Agriculture Polytechnic of \\ Samarinda, 75242, Indonesia \\ suswanto.attala@gmail.com \\ *Corresponding Author
}

\author{
Annafi Franz \\ Software Engineering Technology, \\ Agriculture Polytechnic of \\ Samarinda, 75242, Indonesia \\ annafifranz@gmail.com
}

Submitted: 2021-10-03; Revised: 2021-10-03; Accepted: 2022-02-23; Published: 2022-03-01

\begin{abstract}
Seen from the population administration service in the village still uses a manual system for processing written data and archiving methods as data storage. Therefore, the purpose of this research is to provide better changes to community services by building an accurate and reliable registration and civil registration information system in parianum village, because in the application of community data storage is carried out directly from outlet services to databases by processing data through the website. Waterfall method or often called waterfall model provides a sequential or sequential software lifeline approach starting from analysis, design, coding, testing and supporting stages. Statistical Product and Service Solutions (SPSS) is an application used to perform advanced statistical analysis, data analysis with machine learning algorithms, string analysis, as well as big data analysis that can be integrated to build a data analysis platform. Pearson correlation or often called Correlation Product Moment is a statistical test tool used to test the associative hypothesis (relationship test) of two variables when the data is interval or ratio scale. The results of this study are easy to manage community data in Parianum village.
\end{abstract}

Keywords - Service, Website, Waterfall, Cholera Product Moment, SPSS

\section{INTRODUCTION}

It is realized that the current condition of community service implementation is still faced with a government system that is not efficient and effective and the quality of human resources and apparatus is not adequate. In line with public complaints in general against the services of government agencies, this is because population administration services in the village still use manual systems for written data processing and archiving methods as data storage. Furthermore, causing population data collection or administrative services in general takes a long time and often the existing manual data is no longer accurate. On the other hand, the diversity of society affects the aspirations of the level of needs and abilities, but the community at large has similar expectations and desires for public services. Because information technology does not know the dimensions of space and time, so the service can be close to the community to increase the scope of service. While the information of population registration and civil registration becomes accurate and reliable, because the recording of data directly from outlet service to databases and data processing without human intervention. The formulation of the following problems: How to design and build an administrative service information system based on WEB, How to assist the village apparatus in population administration services. The limitations of the problems studied are as follows: Creation of Certificate or Introduction, Processing of Population, Population Mutation in, moving, birth and death, Processing outgoing letter data and incoming mail

\section{LITERATURE STUDIES}

\section{A. Literature Studies}

Some of the studies used as references and guidelines in the creation of applications include:

Research conducted by Nabila Khaerunnisa and Nofiyati (2020), with his research entitled "Sistem Informasi Pelayanan Administrasi Kependudukan Berbasis Web: Studi Kasus Desa Sidakangen Purbalingga. Teknik Informatika". The purpose of this study is to process population administration services in the search for population data, the administrative process of making cover letters, births and deaths that take time and difficulty to get a quick and accurate population administration report in a short time. Blackbox Testing is a model or method of software testing that is focused on the functionality of the software tested.

Research conducted by Mifthul Huda, Slamet Wiyono, M. Fikri Hidayatullah and Saeful Bahri (2020), with a study entitled "Studi Kasus Sistem Informasi dan Pelayanan Administrasi Kependudukan". Sidamulya village is an administrative area of Warureja subdistrict of Tegal regency, Central Java province. Sidamulya village as a village far from the center of government cannot be separated from the common village problems. The problem that occurs in the village is that 
there are often community complaints related to population administration services that take a lot of time and village information that is not spread to the community. The purpose of this research is to facilitate the community in obtaining information and villages and facilitate the community in managing population administration.

Research conducted by Eti Rohaeti and Dadan Zaliluddin (2018), with a study entitled "Perancangan Sistem Informasi Manajemen Administrasi Desa Berbasis Web: Studi Kasus Pada Desa Tegalsari Kecamatan Maja Kabupaten Majalengka". The purpose of this research is "to form a unity of mutual interaction and cooperation between parts with each other to perform data processing functions, receive input in the form of data, and then process it and issue output in the form of information to support operational and managerial activities in the data system in the village / village. The development of information technology that can improve performance so as to improve the high quality of work, employees that include internal government activities in an institution and government services for the community

Research conducted by Annisa Dwi Rahmawati and Azizah Fatmawati (2020) with a study entitled "Sistem Informasi Desa Mendiro Kecamatan Ngrambe Kabupaten Ngawi Berbasis WEB". The existence of a computerized system also facilitates and accelerates the search for existing data, and the system can be used for the creation of mail management reports, namely mail interception.

Research conducted by Aziz Musthafa and Shoffin Nahwa Utama (2018) with a study entitled "IPTEK Bagi Masyarakat Sistem Informasi Manajemen Administrasi Desa Berbasis Web Di Desa Sekaran Kecamatan Siman Ponorogo". In the system of population administration services in the village is currently still conventional or manual, such as, recording of villagers' data in register books, archival data collection, especially correspondence has not implemented an application-based information system. Therefore, a system is needed to overcome existing problems. One of the features that SIMADES has is the village population administration data processing service in the form of Web applications.

\section{B. Theoretical Foundation}

\section{Information system}

An information system is an orderly combination of people, hardware, software, communication networks and data resources that collect, transform and disseminate information within an organization. (Anggraeni and Irviani, 2017)

\section{Service}

Service can basically be defined as the activities of a person, group or organization either directly or indirectly to meet needs. Moenir said that service is the process of meeting needs through the activities of others directly. (Rianto, 2012)

3. Administration

Administration comes from Latin: Ad = intensive and Ministries =, helping, fulfilling. Administration in a narrow sense is as an office administration activity. Administration is a process that generally exists in the efforts of, government or private, civilian or military, large or small to complete joint tasks. (Rahman, 2017)

4. Community Administration Services

Village Community Administration Service is a community service unit in each village that aims to improve the quality of service and bring services closer to the community. (Syah, 2018)

\section{Website}

A website is the entire web page of a domain that contains information. A website is usually built on many interconnected Web pages. The relationship between one Web page and another is called a hyperlink, while the text used as a connecting medium is called hypertext. (Yuhefizar et al, 2011)

\section{Domain}

Domain is a unique name owned by an institution so that it can be accessed through the internet, for example lintau.com, yahoo.com, google.com, ephi.web.id and others. (Yuhefizar et al, 2011)

7. HypertText Markup Language

HTML stands for HyperText Markup Language which is a semi-programming code on which the Web is based. The code used in HTML is called tags. In 1994 the W3C (Word Wide Web Consortium) was established as the sole authority for Web development and was authorized to establish the standards applicable therein. (Anhar, 2012)

8. Hypertext Preprocessor

PHP stands for Hypertext Preprocessor, and open source Web server programming language. PHP is a script that integrates with HTML and resides on a server (server side HTML embedded scripting). PHP is a script used to create dynamic website pages. Dynamic means that the displayed page is created as well as the page is requested by the client. This mechanism causes the information received by the client to always be up to date. All PHP scripts are executed on the server on which they are executed. (Anhar, 2012)

\section{MySQL}

MySQL is a database management system (database management using SQL commands (Structured Query Language) which is quite well known. This multi-user and multi-flow MySQL management system (DBMS) database is already used by more than 6 million users worldwide. (Setyawan and Pratiwi, 2020)

10. Unified Modelling Language

UML is one of the most widely used language standards in the industrial world to define reqruitment, create analysis and design, as well as describe architecture in object-oriented programming. (Rosa and Shalahuddin, 2018)

\section{Bootstrap}

Bootstrap has provided a collection of basic class interface components that have been designed in such a way as to create an attractive, clean and lightweight. In addition, bootstrap also has a grid 
feature that serves to set layouts that can be used very easily and quickly. (Sanjaya and Hesinto, 2017)

12. Statistical Package for the Socialt Sciences

SPSS is an application used to perform advanced statistical analysis, data analysis with machine learning algorithms, string analysis, as well as big data analysis that can be integrated to build data analysis platforms. Quantitative research produces output in the form of statistical numbers in either descriptive or inferential data. Quantitative analysis is used by researchers if they want to dissect the topic by taking measurements. (Zein et al, 2019)

\section{Correlation Product Moment}

Pearson correlation or often called Correlation Product Moment (KPM) is a statistical test tool used to test the associative hypothesis (relationship test) of two variables when the data is interval or ratio scale. KPM was developed by Karl Pearson. KPM is a form of parametric statistics because it tests data on interval or ratio scales. (Zein et al, 2019)

\section{Black Box Testing}

Black Box Testing focuses on the functional specifications of the software. The tester can define a set of input conditions and perform tests on the functional specifications of the program. Black Box Testing is not an alternative solution to White Box Testing but rather a complement to testing things that are not covered by White Box Testing. (Mustaqbal et al, 2015)

\section{RESEARCH METHODS}

A. Tools and Materials

The tools and materials used for the research are:

1. Acer Aspire V5-471G windows 10 Pro laptop (5 GB RAM, Intel(R) core(TM) i3-3217U processor).

2. Software

3. Xampp

4. Sublime

5. Microsoft Word and Excel

6. StartUML

7. Adobe XD

8. SPSS

9. Population Data

10. Mail Data

\section{B. Waterfall Method}

Waterfall models are often also called sequential linear models or classic life cycles. The waterfall model provides a sequential or sequential software lifeline approach starting from analysis, design, coding, testing and support stages. (Rosa and Shalahuddin, 2018). Waterfall model seen in picture 1 .

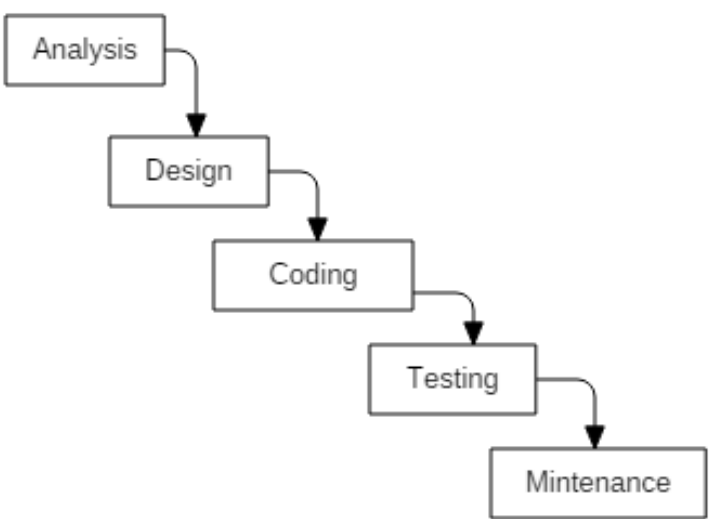

Picture 1. Waterfall Model

Analysis is done with several steps, the first step is to identify the problem that occurred. The second step is to analyze the needs needed to overcome the problem. The third step is to determine the method of data collection. The last step is to analyze the design of the system.

Software design is a multi-step process that focuses on the design of software program creation including data structures, software architectures, interface representations, and coding procedures. This stage translates software needs from the needs analysis stage to the design representation in order to be implemented into a program at a later stage. The design of the software produced at this stage also needs to be documented.

Coding must be translated into the software program. The result of this stage is a computer program in accordance with the design that has been made at the design stage. Programming languages used in web creation are Hyper Text Markup Language (HTML), Hypertext Preprocessor (PHP), Cascading Style Sheet (CSS) and MySQL using PhpMyAdmin.

System testing focuses on software in terms of logic, functional and ensures that all parts are tested. This is done to minimize errors (errors) and ensure the resulting output is in accordance with the desired.

At the maintenance stage does not rule out the possibility of a software experiencing changes when it has been delivered to the user. Changes may occur due to errors that appear and are not detected when testing or software development has to adapt to the new environment. The support stage or maintenance stage may repeat the development process ranging from specification analysis to changes to existing software changes, but not to creating new software.

\section{System Plan}

1. Flowchart System

A system flowchart is a chart that shows the workflow or what is being worked on in the system as a whole and describes the order of the procedures in the system. In other words, this flowchart is a graphical description of the sequence of procedures that combine and form a system. (Rosa and Shalahuddin, 2018) 
In this case, the system requires the internet to access the Web, then the user opens a Web page to perform a search, the user can immediately see the village home page. If the user has entered the home page, the user can choose the government menu and the user chooses the letter you want to create. Next the user will input the data, then the web will display a message completing the requirements and taking the letter. Flowchart system can be seen in picture 2 .

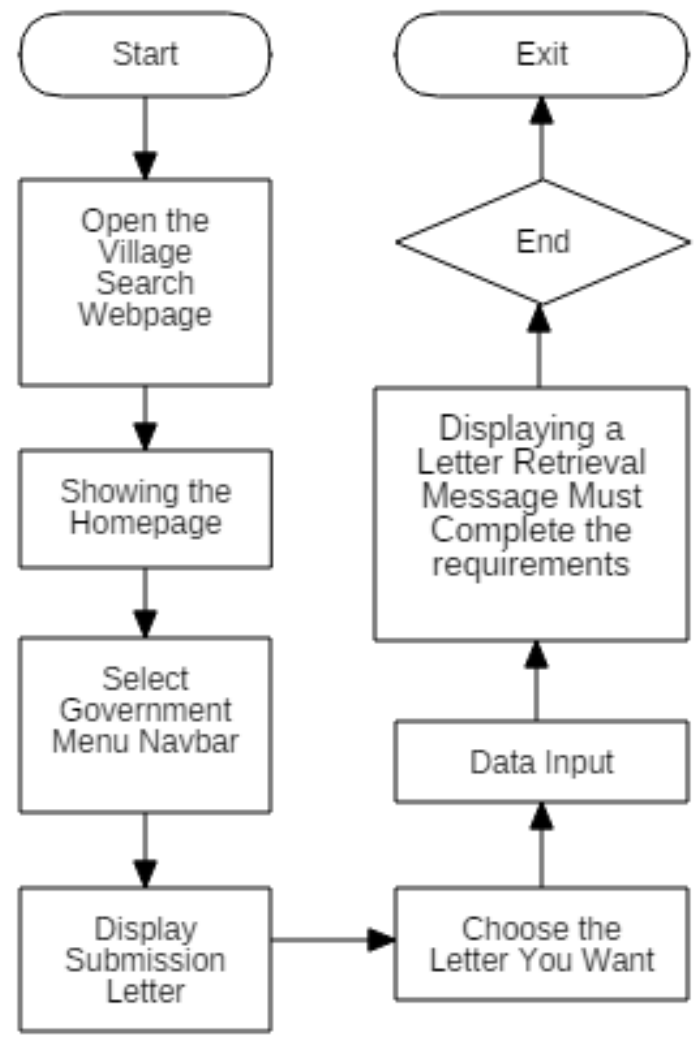

Picture 2. Flowchart System

\section{Use Case Diagram}

Use case diagram is a modeling to perform (behavior) information systems to be created. A use case describes an interaction between one or more actors and the information system to be created. (Rosa and Shalahuddin, 2018)

In this diagram provides an explanation that in the information system using two actors, namely, admin and user. Actor admin in charge of managing mail type pages, namely, adding data, editing data, deleting data and managing population and mail data. But before managing the data, admin is required to login system first. Furthermore, the user actor can choose the desired letter, do the data input, then the letter can be taken at the village office. The use case can be seen in picture 3 .

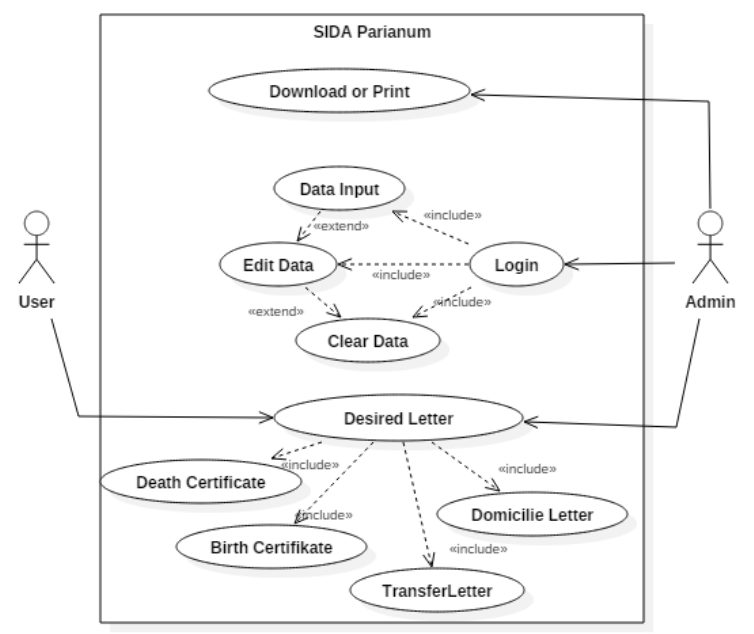

Picture 3. Use Case Diagram

3. Class Diagram

Class diagrams or class diagrams describe the structure of the system in terms of defining classes classes to be created to build the system. (Rosa and Shalahuddin, 2008). Class diagram can be seen in picture 4

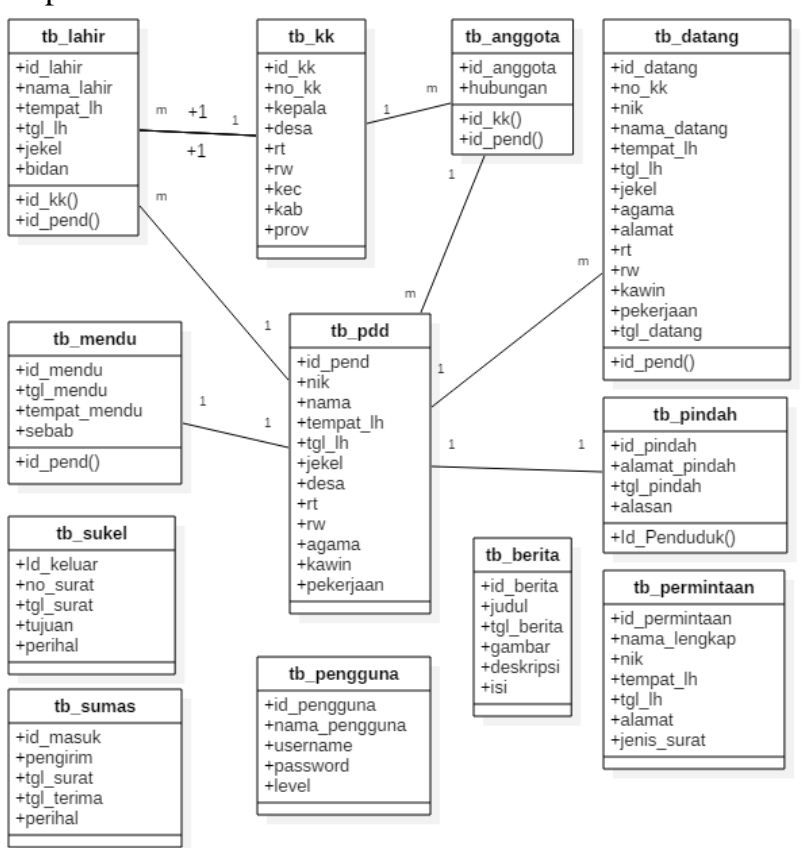

Picture 4. Class Diagram

\section{RESULTS AND DISCUSSIONS}

Here is a look at the results of web creation from the Information Systems Application of Community Administration. This web was created by researchers to produce an Information System of Parianum Village Community Administration Services Based on Websites at the Parianum Village office of Muara Bengkal Subdistrict. This application consists of 2 (two) users, namely User Administrator and User visitor. On the Administrator (Back-End) page there is a login menu, dashboard menu, data management menu, population circulation menu, mail management menu, report management menu and system user menu. The visitor 
page (Front-End) has a Home menu, Village Profile menu, Government menu and Contact us menu.

\section{A. Login Page}

Login is a process of logging into a computer network by entering a minimum account identity consisting of a username/ user account and password to get access rights. Between the username and password both when used for login must be precise not to be typos, because the two are interrelated and cannot be separated. On this login page there are two user accounts of system users, namely administrator and Kaur Government. Username/ user account and password/ password can only be changed by the admin as needed to maintain the security of the Parianum Village Information System website account. The login page can be viewed in picture 5 .

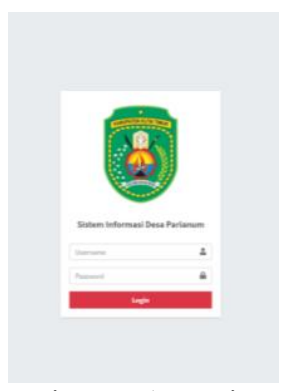

Picture 5. Login

\section{B. Dashboard Page}

The dashboard page view is the central control panel of the website for default settings, which contains several control menus such as population data, family card data, and birth data, coming to death, immigrant/domicile data, moving data and mail generation request data. The dashboard page can be viewed in picture 6 .
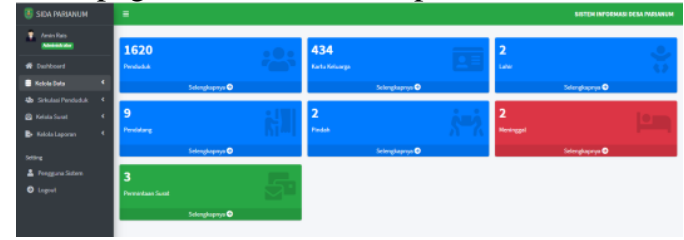

Picture 6. Dashboard

\section{Manage Data page}

Manage data page is part of a sub menu that contains the population data menu and family card display data menu where admins can add data, delete, edit and view population details. Population Data is individual data and / or aggregate data that is structured as a result of population registration activities contained in the SIDA Parianum website by inputting data online. The manage population data page can be viewed in picture 7 .

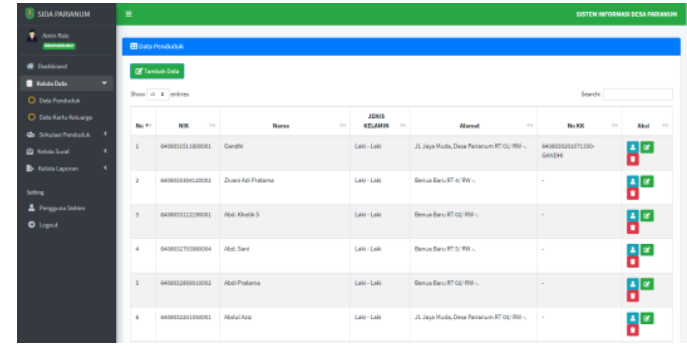

Picture 7. Manage Population Data 1

Family card data is family group data consisting of family heads and family members that are structured as a result of activities posted on the SIDA Parianum website by inputting data online. Managing family card data page can be viewed in Picture 8 .

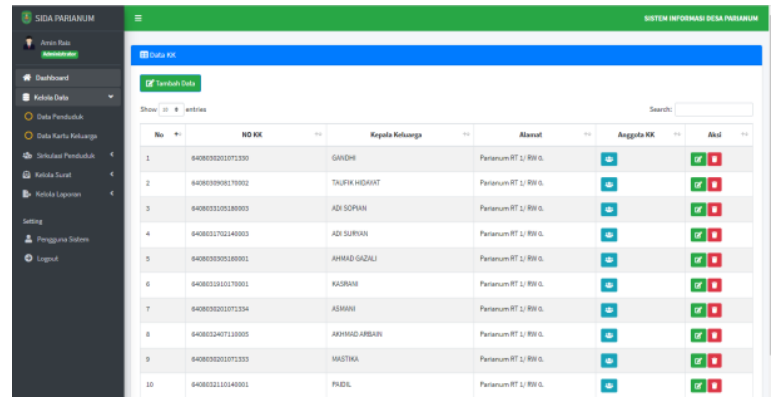

Picture 8. Manage Population Data 2

\section{Population Circulation Page}

Population circulation is a form of non-sedentary population movement, but there are also those who live or live for a while in the destination area. On this page there are several menus such as birth data management, death data, moving data and domicile data / entrants where admins can add data, delete and view details of birth data, death data, transfer data and domicile / immigrant data.

Birth data is newborn data from every resident in parianum village. The birth data page can be seen in picture 9 .

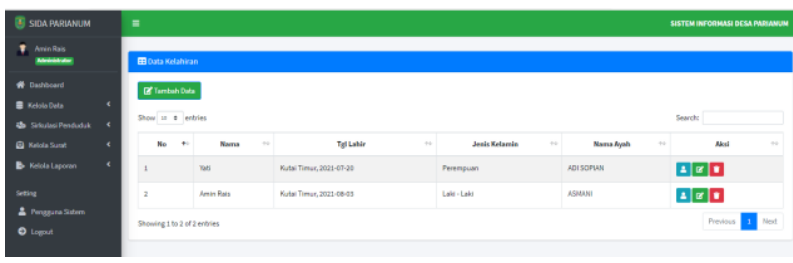

Picture 9. Birth Data

Death data is data of deceased residents from every resident who is in parianum village. The dead data page can be seen in picture 10 


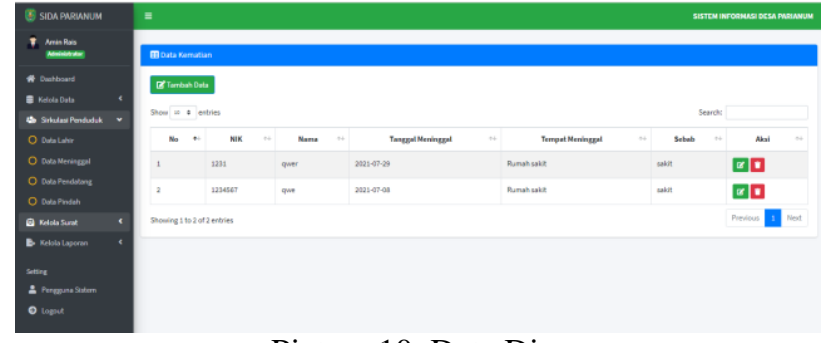

Picture 10. Data Dies

Data hometown is the recording of residents who come due to mutations of moving from outside the area and have qualified - the condition to move in the village of Parianum. The domicile data page can be seen in picture 11 .

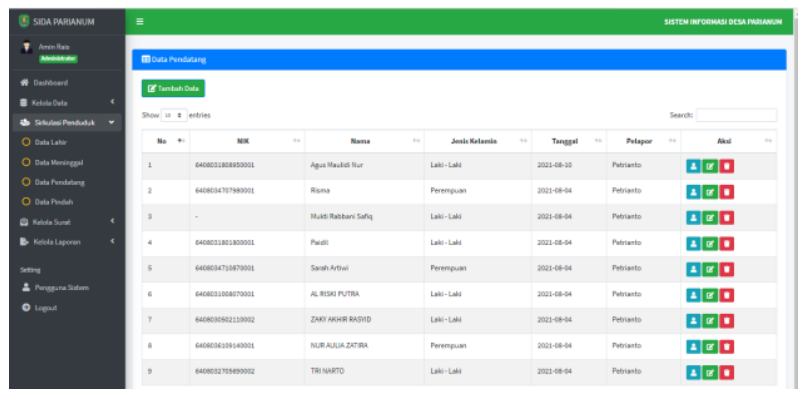

Picture 11. Domicile Data

Moving data is the recording of residents who move at a new address based on the needs concerned. The moving data page can be seen in picture 12 .

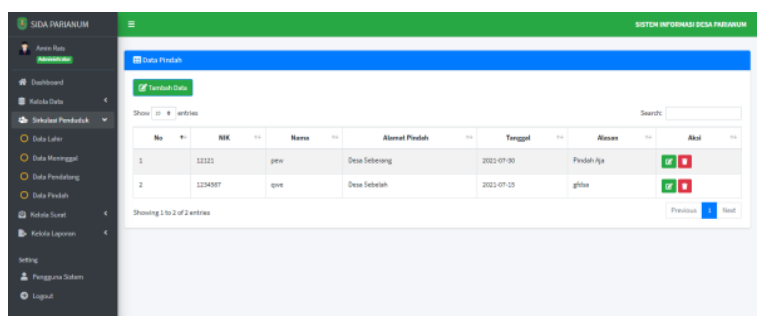

Picture 12. Data Moving House

\section{E. Manage Mail page}

On this page there are four menus, namely: birth certificate, death certificate, transfer certificate and domicile certificate or come then admin enter NIK or resident name after the name of the validated resident or appropriate then the letter in print. The manage mail page can be viewed in picture 13 .

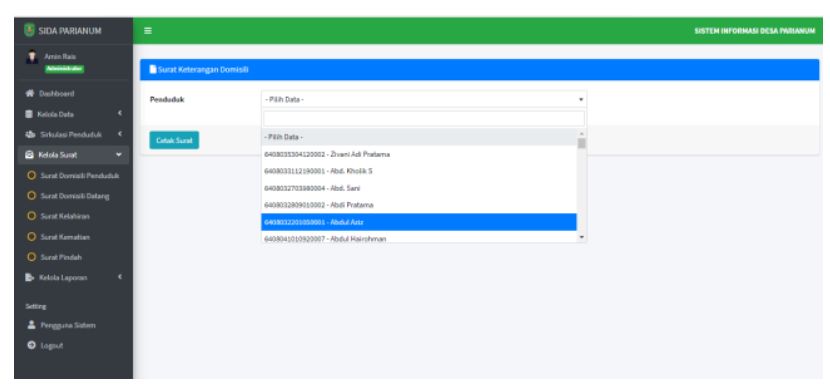

Picture 13. Manage Mail
The result of the letter is the output of the letter printed based on the name of the resident who will create the letter. The results of the letter can be seen in picture 14.
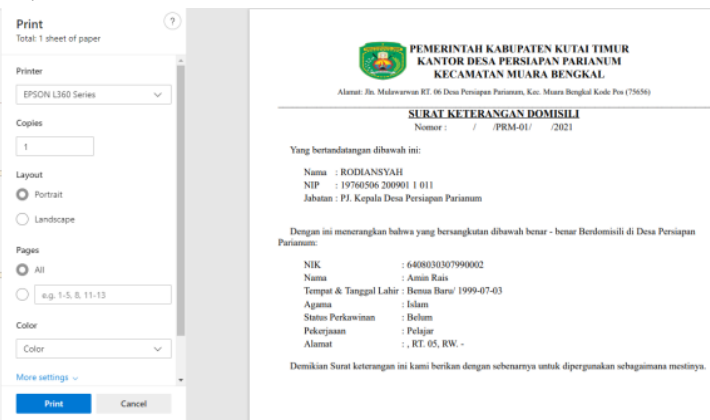

Picture 14. Mail Printout

\section{F. Manage Reports page}

On the manage report page there are 4 (four) menus, namely: manage news, manage mail creation requests, incoming and outgoing letters, on this page we input incoming and outgoing mail data manually

Manage news is text that reports events, events or information about something that has happened or information to be created. By reading the news, we can get various information about something that is in Parianum village. The manage news page can be viewed in picture 15 .
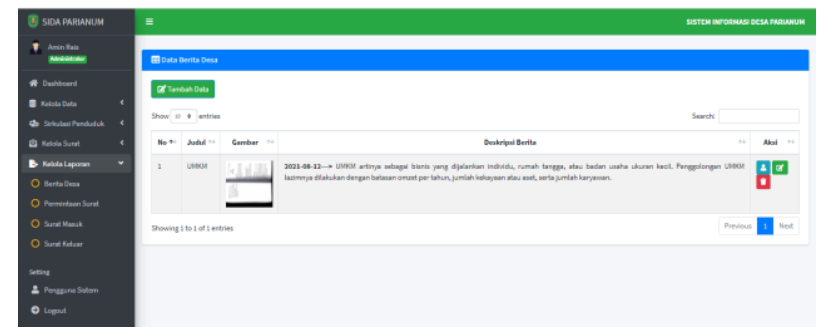

Picture 15. Manage News

On this page describes the part of managing mail requests from letter inputs made by the community. The manage mail requests page can be viewed in picture 16 .

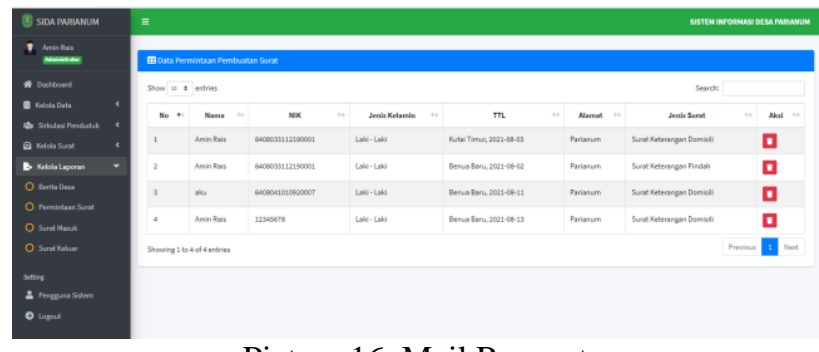

Picture 16. Mail Request

On this page, the function of managing incoming letters is as a history / information for admins as recording incoming letters from agencies / offices. Managing incoming mail page can be seen in picture 17 . 

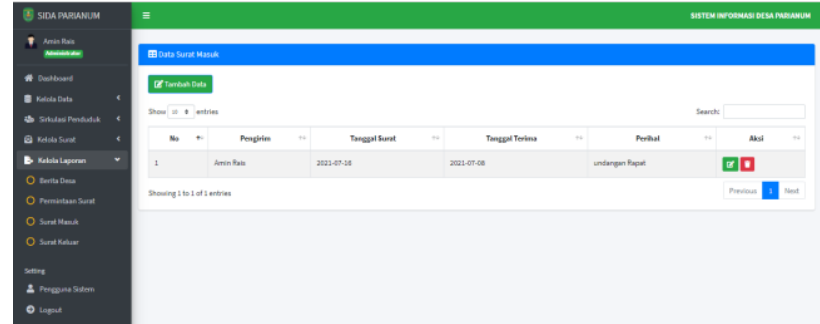

Picture 17. Manage Incoming Mail

The exit letter management page is a request for an exit letter for the community or residents around Parianum Village as a request / personal interest. The managing outgoing mail page can be viewed in picture 18.

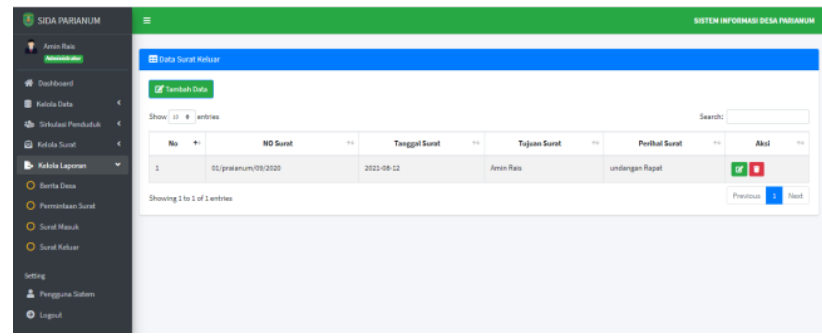

Picture 18. Manage Outgoing Mail

On the manage reports page there are two system users: administrator and government administrator. The system user page can be viewed in picture 19 .
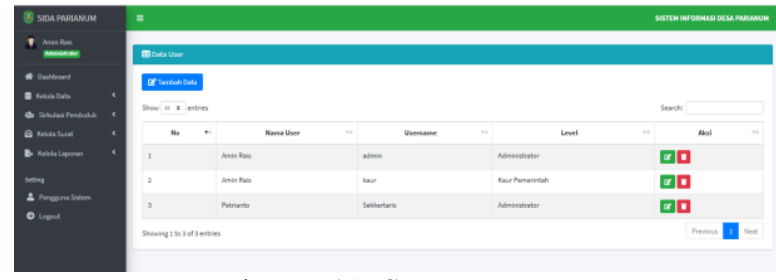

Picture 19. System Users

\section{G. Government Page}

On this page displays the menu view for the selection of letters they want to give to users/ citizens who want to make letters for their benefit and also make it easier for them (citizens) to make letters. The government page can be seen in picture 20 .

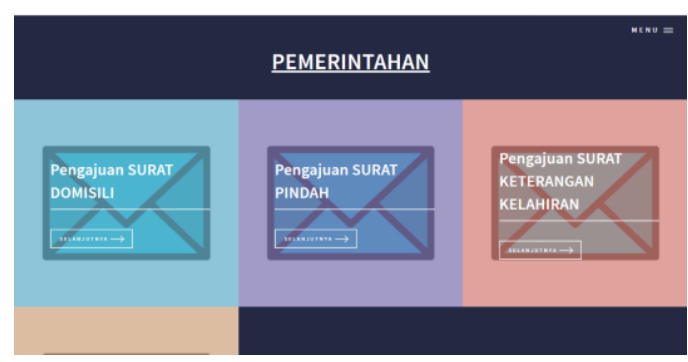

Picture 20. Government Page

On this page is one of the display of the selected data input form. Domicile certificate, from all views there is information about the requirements for the collection of letters at the village office and there is also a filling of letters for their (residents') needs. The data input form can be seen in picture 21 .

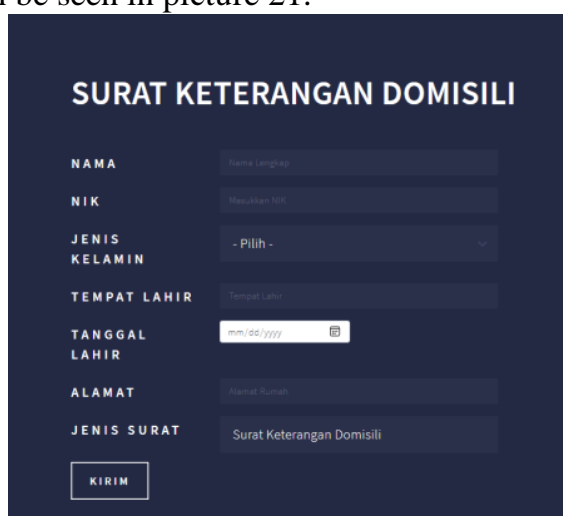

Picture 21. Self Data Input Form

\section{H. System Testing}

System testing is done by running the system on localhost first to find out the weaknesses of the system built before it is implemented, test the menus on the website, and test the ability of admins in managing the information on the website so that when the information displayed there is no error between admins and website users. This is done to minimize errors (errors)and ensure the resulting output is as desired in testing this application the author performs the test using validation tests using SPSS (Statistical Product and Service Solutions). Cholerate validation testing using SPSS form can be seen in table 1 .

Table 1. Cholera Validation Testing Using SPSS

\begin{tabular}{|c|c|c|c|c|c|c|c|c|c|c|c|c|}
\hline \multirow{4}{*}{ Q1 } & lation & \begin{tabular}{|l|} 
Q1 \\
\end{tabular} & $\mathrm{Q} 2$ & Q3 & Q4 & Q5 & Q6 & Q7 & Q8 & \begin{tabular}{|l|} 
Q99 \\
\end{tabular} & Q10 & Results \\
\hline & \begin{tabular}{|c|} 
Pearso \\
$\mathrm{n}$ \\
Correla \\
tion \\
\end{tabular} & 1 & 245 &, 357 &, 275 & ,434 &, 337 & ,345 & $\mid, 476$ &, 420 & ,398 & ,593*** \\
\hline & \begin{tabular}{|l|}
$\begin{array}{l}\text { Sig. (2- } \\
\text { tailed) }\end{array}$ \\
\end{tabular} & &, 176 &, 045 &, 128 & 013 &, 059 & 053 & ,006 &, 017 & ,024 & ,000 \\
\hline & $\mathrm{N}$ & 32 & 32 & 32 & 32 & 32 & 32 & 32 & 32 & 32 & 32 & 32 \\
\hline \multirow[t]{3}{*}{ Q2 } & \begin{tabular}{|c|} 
Pearso \\
$\mathrm{n}$ \\
Correla \\
tion \\
\end{tabular} & ,245 & 1 & , 666 &, 503 & , 486 & , 358 &, 519 & $\mid, 482$ & ,566 & ,701 & ,769*** \\
\hline & \begin{tabular}{|l|}
$\begin{array}{l}\text { Sig. (2- } \\
\text { tailed) }\end{array}$ \\
\end{tabular} & ,176 & &, 000 &, 003 & ,005 &, 045 & ,002 & ,005 &, 001 & 000 & ,000 \\
\hline & $\mathrm{N}$ & 32 & 32 & 32 & 32 & 32 & 32 & 32 & 32 & 32 & 32 & 32 \\
\hline \multirow[t]{3}{*}{ Q3 } & \begin{tabular}{|c|} 
Pearso \\
$\mathrm{n}$ \\
Correla \\
tion \\
\end{tabular} & , 357 & ,666 & 1 & 407 & ,376 & \begin{tabular}{|l|}
, 585 \\
$* * * *$
\end{tabular} & ,393 & $\mid \begin{array}{l}702 \\
* *\end{array}$ & 538 & 668 & ,799** \\
\hline & \begin{tabular}{|l|}
$\begin{array}{l}\text { Sig. (2- } \\
\text { tailed) }\end{array}$ \\
\end{tabular} & , 045 & ,000 & &, 021 & ,034 &, 000 & ,026 &, 000 &, 002 & 000 & ,000 \\
\hline & $\mathrm{N}$ & \begin{tabular}{|l|}
32 \\
\end{tabular} & 32 & 32 & 32 & 32 & 32 & 32 & 32 & 32 & 32 & 32 \\
\hline \multirow[t]{3}{*}{ Q4 } & \begin{tabular}{|c|} 
Pearso \\
$\mathrm{n}$ \\
Correla \\
tion \\
\end{tabular} & ,275 &, $503^{* *}$ & 407 & 1 & ,494 & 396 & ,223 & 371 & $\mid, 342$ & ,580 & ,638** \\
\hline & \begin{tabular}{|l|}
$\begin{array}{l}\text { Sig. (2- } \\
\text { tailed) }\end{array}$ \\
\end{tabular} & , 128 & ,003 &, 021 & & ,004 &, 025 & ,220 &, 037 & ,055 & 001 & ,000 \\
\hline & $\mathrm{N}$ & \begin{tabular}{|l|}
32 \\
\end{tabular} & 32 & \begin{tabular}{|l|}
32 \\
\end{tabular} & 32 & \begin{tabular}{|l|}
32 \\
\end{tabular} & 32 & 32 & 32 & \begin{tabular}{|l|}
32 \\
\end{tabular} & 32 & 32 \\
\hline \multirow[t]{3}{*}{ Q5 } & \begin{tabular}{|c|} 
Pearso \\
$n$ \\
Correla \\
tion \\
\end{tabular} & ,434 &, $486^{* * *}$ & $\begin{array}{l}376 \\
*\end{array}$ & 494 & 1 & , 406 & ,311 &, 331 &, 351 & ,607 & ,684*** \\
\hline & \begin{tabular}{|l|} 
Sig. (2) \\
tailed)
\end{tabular} & ,013 & ,005 & ,034 & 004 & &, 021 & ,083 & ,065 &, 049 & ,000 & ,000 \\
\hline & $\mathrm{N}$ & 32 & 32 & 32 & 32 & 32 & 32 & 32 & 32 & 32 & 32 & 32 \\
\hline Q6 & \begin{tabular}{|c|} 
Pearso \\
$\mathrm{n}$ \\
Correla \\
tion
\end{tabular} & ,337 &, $358^{*}$ & 585 & 396 & , 406 & 1 &, 551 & ,647 &, 088 & ,454 &, $683^{* *}$ \\
\hline
\end{tabular}




\begin{tabular}{|c|c|c|c|c|c|c|c|c|c|c|c|c|}
\hline \multicolumn{2}{|c|}{ Correlation } & Q1 & $\mathrm{Q} 2$ & Q3 & Q4 & Q5 & Q6 & Q7 & Q8 & Q9 & Q10 & Results \\
\hline & $\begin{array}{l}\text { Sig. (2- } \\
\text { tailed) }\end{array}$ & ,059 & ,045 & ,000 & ,025 &, 021 & &, 001 &, 000 & ,630 & 2009, & ,000 \\
\hline & $\mathrm{N}$ & 32 & 32 & 32 & 32 & 32 & 32 & 32 & 32 & 32 & 32 & 32 \\
\hline \multirow[t]{3}{*}{ Q7 } & $\begin{array}{c}\text { Pearso } \\
n \\
\text { Correla } \\
\text { tion }\end{array}$ & ,345 &, $519^{* *}$ & ,393 & ,223 &, 311 &, 551 & 1 &, 547 & ,409 & ,418 &, $648^{* *}$ \\
\hline & $\begin{array}{l}\text { Sig. (2- } \\
\text { tailed) }\end{array}$ & ,053 & ,002 & ,026 & ,220 &, 083 &, 001 & &, 001 & ,020 & ,017 & ,000 \\
\hline & $\mathrm{N}$ & 32 & 32 & 32 & 32 & 32 & 32 & 32 & 32 & 32 & 32 & 32 \\
\hline \multirow[t]{3}{*}{ Q8 } & $\begin{array}{c}\text { Pearso } \\
n \\
\text { Correla } \\
\text { tion }\end{array}$ & ${ }_{* * *}^{476}$ &, $482^{* * *}$ &, 702 &, 371 &, 331 &, 647 &, 547 & 1 & , 498 & ,647 &, $790^{* * *}$ \\
\hline & $\begin{array}{l}\text { Sig. (2- } \\
\text { tailed) }\end{array}$ & ,006 & ,005, & ,000 & ,037 &, 065 & ,000 & ,001 & & ,004 & ,000, & ,000 \\
\hline & $\mathrm{N}$ & 32 & 32 & 32 & 32 & 32 & 32 & 32 & 32 & 32 & 32 & 32 \\
\hline \multirow[t]{3}{*}{ Q9 } & $\begin{array}{c}\text { Pearso } \\
n \\
\text { Correla } \\
\text { tion }\end{array}$ & ,420 &, $566^{* *}$ &, 538 & ,342 &, 351 & ,088 &, 409 &, 498 & 1 &, 714 & $682^{* *}$ \\
\hline & $\begin{array}{l}\text { Sig. (2- } \\
\text { tailed) }\end{array}$ & ,017 & ,001 & ,002 & ,055 &, 049 & ,630 &, 020 & ,004 & & ,000, & ,000 \\
\hline & $\mathrm{N}$ & 32 & 32 & 32 & 32 & 32 & 32 & 32 & 32 & 32 & 32 & 32 \\
\hline \multirow{3}{*}{$\begin{array}{c}\mathrm{Q} \\
10\end{array}$} & $\begin{array}{c}\text { Pearso } \\
n \\
\text { Correla } \\
\text { tion } \\
\end{array}$ & ,398 &, $701^{* *}$ & ,668 &, 580 &, 607 &, 454 &, 418 &, 647 &, 714 & 1 &, $869^{* *}$ \\
\hline & $\begin{array}{l}\text { Sig. (2- } \\
\text { tailed) }\end{array}$ & ,024 & ,000 & ,000 & ,001 &, 000 & ,009 &, 017 &, 000 &, 000 & & ,000 \\
\hline & $\mathrm{N}$ & 32 & 32 & 32 & 32 & 32 & 32 & 32 & 32 & 32 & 32 & 32 \\
\hline \multirow[t]{3}{*}{ Results } & \begin{tabular}{|c|} 
Pearso \\
$n$ \\
Correla \\
tion \\
\end{tabular} &, 593 &, $769^{* *}$ & ,799 & ,638 &, 684 &, 683 &, 648 & $\begin{array}{l}, 790 \\
{ }^{*} * *\end{array}$ & ,682 & 869 & 1 \\
\hline & $\begin{array}{l}\text { Sig. (2- } \\
\text { tailed) }\end{array}$ & , 000 & ,000 & ,000 & ,000 &, 000 &, 000 &, 000 & ,000 & ,000 & ,000 & \\
\hline & $\mathrm{N}$ & 32 & 32 & 32 & 32 & \begin{tabular}{|l|}
32 \\
\end{tabular} & \begin{tabular}{|l|}
32 \\
\end{tabular} & 32 & 32 & 32 & 32 & 32 \\
\hline
\end{tabular}

The result of observation on $\mathrm{r}$-Tabel obtained a value from the sample $(\mathrm{N})=32$ of 0.349 , so referring to the result of the validity test resulted that all question variables consisting of 10 questions are all valid.

Testing the results of respondents there were 32 people including village officials and Parianum village community and there were 10 questionnaire questions with answer options that are very agreeable, agree, disagree, disagree and strongly disagree. Based on the results obtained from the respondents' promotions, the average score is the highest value of $57.2 \%$ with the agreed category, the value of $36.6 \%$ with the category strongly agrees, the value of $6.3 \%$ with the category of disagreeing and the value of $0 \%$ with the category of disagreeing and strongly disagreeing. Respondent test form can be seen in table 2 .

Table 2. Respondent Test

\begin{tabular}{|l|c|c|c|}
\hline \multirow{2}{*}{\multicolumn{1}{|c|}{ Question }} & \multicolumn{3}{|c|}{ Number Of Respondents } \\
\cline { 2 - 4 } & $\begin{array}{c}\text { Strongly } \\
\text { Agree }\end{array}$ & Agree & Diagree \\
\hline $\begin{array}{l}\text { Interesting app } \\
\text { look? }\end{array}$ & $11(34,4 \%)$ & $20(62,5 \%)$ & $1(3,1 \%)$ \\
\hline $\begin{array}{l}\text { Is the web } \\
\text { application easy } \\
\text { to use? }\end{array}$ & $13(40,6 \%)$ & $18(56,3 \%)$ & $1(3,1 \%)$ \\
\hline $\begin{array}{l}\text { All the features } \\
\text { are easy to use on } \\
\text { web applications? }\end{array}$ & $\begin{array}{c}13 \\
(40,6 \%)\end{array}$ & $17(53,1 \%)$ & $2(6,3 \%)$ \\
\hline $\begin{array}{l}\text { Can writing on } \\
\text { the web be read } \\
\text { easily? }\end{array}$ & $\begin{array}{l}15 \\
(46,9 \%)\end{array}$ & $17(53,1 \%)$ & $0(0 \%)$ \\
\hline
\end{tabular}

\begin{tabular}{|c|c|c|c|}
\hline \multirow[b]{2}{*}{ Question } & \multicolumn{3}{|c|}{ Number Of Respondents } \\
\hline & $\begin{array}{l}\text { Strongly } \\
\text { Agree }\end{array}$ & Agree & Diagree \\
\hline $\begin{array}{l}\text { Are you } \\
\text { comfortable with } \\
\text { the colors on the } \\
\text { web? }\end{array}$ & $9(28,1 \%)$ & $18(56,3 \%)$ & $\begin{array}{c}5 \\
(15,6 \%)\end{array}$ \\
\hline $\begin{array}{l}\text { Are you easy to } \\
\text { make a letter? }\end{array}$ & $14(43,8 \%)$ & $14(43,8 \%)$ & $\begin{array}{c}4 \\
(12,5 \%) \\
\end{array}$ \\
\hline $\begin{array}{l}\text { Web application } \\
\text { features as } \\
\text { needed? }\end{array}$ & $8(25,0 \%)$ & $23(71,9 \%)$ & $1(3,1 \%)$ \\
\hline $\begin{array}{l}\text { The language } \\
\text { used in web } \\
\text { applications is } \\
\text { easy to } \\
\text { understand? }\end{array}$ & $13(40,6 \%)$ & $19(59,4 \%)$ & $0(0 \%)$ \\
\hline $\begin{array}{l}\text { Is this web } \\
\text { application } \\
\text { already } \\
\text { supporting } \\
\text { administrative } \\
\text { services? }\end{array}$ & $9(28,1 \%)$ & $20(62,5 \%)$ & $3(9,4 \%)$ \\
\hline $\begin{array}{l}\text { Accuracy about } \\
\text { the } \\
\text { implementation of } \\
\text { service time? }\end{array}$ & $12(37,5 \%)$ & $17(53,1 \%)$ & $3(9,4 \%)$ \\
\hline Average & $36,6 \%$ & $57,2 \%$ & $6,3 \%$ \\
\hline
\end{tabular}

\section{Conclusion}

Parianum village community administration information system is designed with web-based using Hyper Text Markup Language (HTML), Hypertext preprocessor (PHP), Cascading Style Sheet (CSS) and MySQL. With the concept of the web that can be accessed by all communities, not only village administrators, the information system that is built is able to help the village in managing its administrative data, so as to improve the village administration process to be easier, faster and accurate and improve integrity related to village data. Based on the results of tests conducted in Parianum village, the 32 most application users chose to agree with 18 people $(57.2 \%)$, strongly agreed with 12 people $(36.6 \%)$, disagreed by 2 people (6.3) and disagreed and strongly disagreed with 0 people $(0 \%)$. From the results of the test respondents can be concluded that respondents feel comfortable and assume that the application is appropriate and can be used by users. Based on the results of validation tests with person's product moment cholera model using the SPSS application of a variable number of 10 questions with a sum of r-Numeracy greater than $\mathrm{r}$-Tabel = 0.349 all questionnaire data is valid.

\section{REFERENCES}

Anggraeni, E. Y., \& Irviani, R. (2017). Pengantar Sistem Informasi. Yogyakarta: CV. Andi Offset.

Anhar. (2012). Panduan Menguasai PHP \& MySQL Secara Otodidak. Jakarta: Mediakita. 
Huda, M., Wiyono, S., Hidayatullah, M. F., \& Bahri, S. (2020). Studi Kasus Sistem Informasi dan Pelayanan Administrasi Kependudukan. Sistem Komputer, 9(1), 59-63.

Khaerunnisa, N., \& Nofiyati. (2020). Sistem Informasi Pelayanan Administrasi Kependudukan Berbasis Web: Studi Kasus Desa Sidakangen Purbalingga. Teknik Informatika, 1(1), 25-33.

Mustaqbal, N. S., Firdaus, R. F., \& Rahmadi, H. (2015). Pengujian Aplikasi Menggunakan Black Box Testing Boundary Value Analysis (Studi Kasus: Aplikasi Prediksi Kelulusan SNMPTN). Jurnal Ilmiah Teknologi Informasi Terapan, 1(3), 31-36.

Musthafa, A., \& Utama, S. N. (2018). IPTEK Bagi Masyarakat Sistem Informasi Manajemen Administrasi Desa Berbasis Web Di Desa Sekaran Kecamatan Siman - Ponorogo. Terapan Abdimas, 3(1), 1-8.

Rahman, M. (2017). Ilmu Administrasi. Makassar: CV. Sah Media.

Rahmawati, A. D., \& Fatmawati, A. (2020). Sistem Informasi Desa Mendiro Kecamatan Ngrambe Kabupaten Ngawi Berbasis WEB. Teknik Elektro, 20(2), 134-140.

Rianto, M. N. (2012). Dasar - Dasar Pemasaran Bank Syari'ah. Bandung: Alfabeta.

Rohaeti, E., \& Zaliluddin, D. (2018). Perancangan Sistem Informasi Manajemen Administrasi Desa Berbasis Web: Studi Kasus Pada Desa Tegalsari Kecamatan Maja Kabupaten Majalengka. Fakultas Teknologi Informasi, Universitas Serang Raya.

Rosa, A. S., \& Shalahuddin, M. (2018). Rekayasa Perangkat Lunak Terstruktur dan Berorintasi Objek, Edisi Revisi. Bandung: Informatika.

Sanjaya, R., \& Hesinto, S. (2017). Rancang Bangun Website Profil Hotel Agung Pribumilah Menggunakan Framework Bootstrap. Sistem Informasi, 1-8.

Setyawan, M. H., \& Pratiwi, D. A. (2020). Membuat Sistem Informasi Gadai Online Menggunakan Codeigniter Serta Kelola Proses Pemberitahuannya. Bandung: Keratif Industri Nusantara.

Syah, S. F. (2018). Efektivitas Pelayanan Administrasi Masyarakat Desa dan Kelurahan (PADMA) Dalam Perwujudan Good Governance (Studi Desa Sambirejo Kecamatan Pluppuh Kabupaten Sragen). Fakultas Hukum Universitas Negeri Semarang.

Yuhefizar, Mooduto, H., \& Hidayat, R. (2011). Cara Mudah Membangun Website Interaktif Menggunakan Content Management Sistem Joomla: Edisi Revisi. Jakarta: PT. Elex Media Komputindo.

Zein, S., Yasyifa, L., Ghozi, R., Harahap, E., Badruzzaman, F., \& Darmawan, D. (2019). Pengolahan Dan Analisis Data Kuantitatif Menggunakan Aplikasi SPSS. Jurnal Teknologi dan Pembelajaran, 4(1), 1-7.). 